УДК 341.62

DOI https://doi.org/10.32849/2663-5313/2020.7.68

Артем Іванов,

аспірант кафедри права Свропейського Союзу

Національного юридичного університету імені Ярослава Мудрого

\title{
МІЖНАРОДНО-ПРАВОВІ ЗАСАДИ ДІЯЛЬНОСТІ ОРГАНІВ, ЩО ЗДІЙСНЮЮТЬ РОЗСЛІДУВАННЯ КАТАСТРОФИ БОЇНГУ 777 НАД ТЕРИТОРІЕЮ ДОНЕЦЬКОЇ ОБЛАСТІ
}

Стаття присвячена аналізу діяльності двох міжнародних слідчих груп, завданням яких було проведення технічного розслідування причин та обставин катастрофи Боїнгу 777-200ЕR, який було збито над територією Донеиької області 17 липня 2014 року, та кримінального розслідування, метою якого є встановлення осіб, винних у катастрофі. Проводиться аналіз положень Конвениії про міжнародну иивільну авіаиію 1944 р. та Додатку 13 до неї, які врегульовують різноманітні аспекти здійснення технічного розслідування авіакатастроф иивільної авіації. Аналізуються також нормативні акти, які регламентують діяльність Об'єднаних слідчих груп, які являють собою механізм міжнародного співробітниитва, заснований на угоді між компетентними органами двох або більше держав, створеними на обмежений термін і для конкретної мети - проведення кримінальних розслідувань в одній або декількох заінтересованих державах. Досліджуються підстави проведення таких розслідувань, їх мета і завдання, суб'єкти, уповноважені на створення відповідних слідчих груп, компетениія та повноваження таких груп, питання, пов'язані з призначенням їх иленів, тощо. У статті визначається міжнародно-правова природа та аналізується безпосередня діяльність слідчих груп, створених для розслідування конкретної події - катастрофи літака, що виконував плановий рейс МН17 над територією України. Досліджуються результати діяльності зазначених органів, що полягають у встановленні ними фактичних обставин справи, виробленні на їх основі висновків щодо причин катастрофи, встановленні індивідуальної відповідальності осіб, винних у ї̈ вчиненні, та наданні рекомендаиій, спрямованих на запобігання таким випадкам у майбутньому. У статті також досліджується питання про те, чи можна відносити зазначені слідчі групи до міжнародних органів з встановлення фактів. Автор доходить висновку, що такі слідчі групи мають характерні риси, притаманні міжнародним слідчим комісіям, та власні специфічні особливості, що відрізняють їх від традиційних органів з встановлення фактів.

Ключові слова: встановлення фактів, обслідування, слідчі комісії, слідчі групи, міжнародне розслідування, авіакатастрофи, цивільна авіація.

Постановка проблеми. 17 липня 2014 р. над територією Донецької області сталася катастрофа авіалайнеру Boeing 777-200ER авіакомпанії Malaysia Airlines, що виконував плановий рейс МН17 за маршрутом Амстердам-Куала-Лумпур. Авіакатастрофа є однією 3 найбільших за всю історію авіації. Загинули всі, хто перебував на борту - 283 пасажира та 15 членів екіпажу.

Виникла необхідність проведення неупередженого міжнародного розслідування причин та обставин катастрофи. У своїй резолюції 2166 (2014) від 21.07.2014 р. Рада Безпеки ООН підкреслила необхідність проведення повного, ретельного і незалежного міжнародного розслідування катастрофи рейсу МН 17 відповідно до керівних принципів міжнародної цивільної авіації [1]. Було проведено декілька розслідувань катастрофи, найбільш вагомими з яких є технічне розслідування причин катастрофи, проведене Радою Безпеки Нідерландів (РБН), та розслідування Об'єднаної слідчої групи (ОСГ), метою якого було кримінальне переслідування осіб, дії яких призвели до катастрофи.

Аналіз останніх досліджень і публікацій. Тематикою мирних засобів вирішення міжнародних спорів загалом та процедури розслідування зокрема займались такі вчені-міжнародники, як А. Х. Абашидзе, Л. М. Анісімов, ван Бовен Т., Е. С. Кривчикова, О. М. Ладиженський, Д. Меріллс, А. П. Мовчан, Е. А. Пушмін, Б. Рамшаран, А. М. Солнцев, М. В. Яновський та інші.

Метою статті $є$ визначення правової природи органів, що здійснюють розслідування катастрофи рейсу МН17, та надання оцінки їхньої діяльності. 
Виклад основного матеріалу. Відповідно до ст. 26 Конвенції про міжнародну цивільну авіацію 1944 р. у разі події з повітряним судном однієї договірної держави, яка сталася на території іншої договірної держави і спричинила смерть або серйозні тілесні ушкодження чи свідчить про серйозний технічний дефект повітряного судна або аеронавігаційних засобів, держава, на території якої сталася пригода, призначає розслідування обставин пригоди згідно з процедурою, яка може бути рекомендована Міжнародною організацією цивільної авіації, наскільки це допускає її законодавство [2]. Ця стаття нерозривно пов'язана зі ст. 37 Конвенції, яка уповноважує IКАО з метою уніфікації правил, стандартів, процедур і організації цивільних авіаперевезень приймати і змінювати міжнародні Стандарти, Рекомендовану практику і процедури, які стосуються в тому числі розслідування пригод [2].

Відповідні положення містяться в Додатку 13 до Конвенції, який детально врегульовує питання, пов'язані з метою, організацією та здійсненням розслідування [3]. Під розслідуванням розуміється процес, що проводиться 3 метою запобігання аваріям, який включає збір та аналіз інформації, підготовку висновків з визначенням причин і у разі потреби вироблення рекомендацій з безпеки [3, с. 11]. Єдиною метою такого розслідування є запобігання аваріям у майбутньому (п. 3.1). Воно має включати: а) збір, фіксацію та аналіз всієї доступної інформації стосовно події; б) визначення причин події; в) вироблення рекомендацій, спрямованих на забезпечення безпеки авіаперельотів; і г) підготовку остаточної доповіді (п. 5.4) [3, с. 21].

За загальним правилом обов'язок з проведення розслідування покладається на державу, на території якої сталася подія. Така держава розпочинає розслідування обставин події і несе відповідальність за його проведення. Водночас проведення такого розслідування повною мірою або в певній його частині може бути делеговано іншій державі за взаємною домовленістю (п. 5.1) [3, с. 20].

Так, Національне бюро з розслідування авіаційних подій та інцидентів із цивільними повітряними суднами України делегувало повноваження 3 проведення розслідування Раді Безпеки Нідерландів відповідно до укладеної між ними угоди [4]. Окрім держави, на яку покладається обов'язок з проведення розслідування, своїх представників до органу, що його здійснює, можуть призначати й інші заінтересовані держави. Ст. 26 Чиказької конвенції встановлює, що державі, в якій зареєстровано повітряне судно, надається можливість призначити спостерігачів для присутності при розслідуванні, а держава, яка проводить розслідування, направляє цій державі звіт і висновок про розслідування. Держава реєстрації, держава оператора, держава розробки і держава виготовлення мають право призначати акредитованого представника для участі в розслідуванні (п. 5.18) [3, с. 24]. Будь-яка держава, яка за запитом надає інформацію, послуги або експертів державі, що проводить розслідування, має право призначити акредитованого представника для участі в розслідуванні (п. 5.23). До складу слідчої групи увійшли представники Нідерландів (держава, відповідальна за розслідування), України (держава події), Малайзії (держава-оператор та держава реєстрації), США (держава розробки і виготовлення судна), Об'єднаного Королівства (держава розробки і виготовлення двигунів), Австралії (держава, що надавала інформацію) та Російської Федерації (держава, що надавала інформацію) [5, с. 15-16]. Окрім цього, державам, що є особливо заінтересованими у розслідуванні події, що призвела до загибелі або серйозних травм своїх громадян, може бути надане право призначення експертів до складу такого органу 3 дозволу держави, що проводить розслідування (п. 5.27) [3, с. 26]. Відповідно до цих положень, до проведення розслідування були залучені експерти з Бельгії, Канади, Німеччини, Індонезії, Ізраїлю, Італії, Нової Зеландії, Філіппін та В'єтнаму [5, с. 16].

Розслідування мало дві основні мети: 1) встановлення причин катастрофи та інформування родичів загиблих та інших заінтересованих сторін про обставини катастрофи та хід розслідування; 2) ініціювання відповідних заходів безпеки з метою мінімізації ймовірності подібних випадків у майбутньому [5, с. 15]. Попередню доповідь слідчої групи було опубліковано 09.09.2014 р., а фінальну доповідь - 13.10.2015 р. У доповіді наводиться докладний опис послідовності подій польоту рейсу МН17 від аеропорту відправлення до наземного удару. У ній описуються та аналізуються питання, пов'язані зі здійсненням польоту, рішення, прийняті Україною щодо використання ї̈ повітряного простору, рішення Малайзійських авіаліній та інших операторів про політ над східною частиною України і взагалі процес прийняття рішення стосовно польоту над зонами конфлікту. У ньому також приділена увага ролі Нідерландів як держави вильоту рейсу МН17 та інших держав щодо польотів над зонами конфлікту [5].

За результатами розслідування було зроблено такі висновки:

1) літак було збито ракетою, встановленою на ракетно-повітряному комплексі Бук. 
Інші ймовірні сценарії катастрофи були відхилені;

2) заінтересовані держави, оператори та IКАО не змогли адекватно оцінити ризики збройного конфлікту на східній частині України для цивільної авіації, вважаючи, що переліт є безпечним;

3) нинішня структура та функціонування системи відповідальності стосовно захисту цивільної авіації не забезпечує достатніх способів для адекватної оцінки ризиків, пов'язаних з польотом над зонами конфлікту [5, с. 253-254].

3 огляду на виявлені недоліки РБН наголосила, що система потребує термінового поліпшення, що стосується правил польоту, способів розподілу і реалізації відповідальності та співпраці між державами. Тому необхідне поліпшення на трьох взаємопов'язаних рівнях. Перший рівень стосується управління повітряним простором в державах, на території яких мають місце збройні конфлікти. Другий рівень стосується оцінки державами й операторами ризиків польоту над зонами конфлікту. Третій рівень стосується відповідальності операторів за їхній вибір: літати чи ні над зонами конфлікту [5, с. 263]. Такі поліпшення потребують внесення змін до положень Чиказької конвенції та Стандартів і Рекомендованої практики ІКАО, у зв'язку з чим були сформульовані такі рекомендації:

Рівень 1 - рекомендації першого рівня були направлені ІКАО та її державамчленам:

1. Рекомендації IКАО:

a) включити до Стандартів положення, відповідно до яких держави, на території яких має місце збройний конфлікт, повинні на ранній стадії публікувати інформацію про характер і масштаби конфлікту та його наслідки для цивільної авіації, а також надати чіткі визначення відповідних термінів, таких як «зони конфлікту» і «збройний конфлікт»;

б) запитувати у держав, на території яких має місце збройний конфлікт, додаткову інформацію та пропонувати допомогу, якщо такі держави не реалізують у повному обсязі свої зобов'язання щодо безпеки простору для цивільної авіації;

в) оновити Стандарти та Рекомендовану практику, що стосуються наслідків збройних конфліктів для цивільної авіації, та максимально переглянути Рекомендовану практику для того, щоб держави могли вживати однозначні заходи, коли йдеться про безпеку цивільної авіації.

2. Рекомендації державам-членам IКАО:

а) забезпечити, щоб зобов'язання держав, пов'язані з безпекою їхнього повітряного про- стору, були більш чітко визначені в Чиказькій конвенції та Рекомендованій практиці, для того щоб було зрозуміло, в яких випадках повітряний простір має бути закрито.

Рівень 2 - рекомендації другого рівня були адресовані ІКАО, Міжнародній асоціації повітряного транспорту та державам операторам. Їх зміст зводився до необхідності провадження оцінки ризиків польоту над зонами конфлікту та розповсюдження інформації про можливі загрози та небезпеки в повітряному просторі.

Рівень 3 - рекомендації третього рівня передбачали надання операторами інформації про маршрути минулих та майбутніх польотів, що має виявлятися у представленні ними публічної звітності стосовно польотів над зонами конфлікту принаймні один раз на рік.

Тут слід зауважити, що розподіл вини або відповідальності не може бути метою діяльності слідчої групи - будь-які судові чи адміністративні провадження стосовно розподілу вини або відповідальності мають бути відокремлені від технічного розслідування [2, с. 21]. Тому з метою встановлення осіб, винних у катастрофі рейсу МН17, було створено Об'єднану слідчу групу, завдання якої полягає у проведенні кримінального розслідування.

Об'єднана слідча група - це інструмент міжнародного співробітництва, заснований на угоді між компетентними органами (судовими та/або правоохоронними) двох або більше держав, створеними на обмежений термін і для конкретної мети - проведення кримінальних розслідувань в одній або декількох заінтересованих державах [6, с. 4].

Об'єднані слідчі групи $є$ механізмом, що функціонує насамперед в рамках Європейського Союзу. Можливість створення ОСГ між державами-членами передбачена ст. 13 Конвенції про взаємну правову допомогу у кримінальних справах між державами-членами Європейського Союзу [7]. 13.06.2002 р. Рада $Є C$ прийняла рамкове рішення 2002/465/JНА про об'єднані слідчі групи, яке держави-члени мали виконати до 01.01.2003 р. [8]. Окрім цього, створення ОСГ передбачене в ст. 20 Другого додаткового протоколу від 08.11.2001 р. до Європейської конвенції про взаємну допомогу у кримінальних справах 1959 р. [9]. Положення зазначених нормативних актів ідентично регулюють діяльність ОСГ.

Звернення до механізму об'єднаних слідчих груп можливе у двох конкретних ситуаціях:

1) $є$ необхідність проведення транскордонних розслідувань - коли розслідування 
кримінальних злочинів вимагає складних розслідувань, пов'язаних 3 іншими державами-членами;

2) пов'язані між собою розслідування вимагають координації - ряд держав-членів проводять розслідування кримінальних злочинів, в яких обставини справи вимагають скоординованих, узгоджених дій у відповідних державах-членах [6, с. 6].

Основними суб'єктами, уповноваженими на створення ОСГ, є держави-члени СС. Однак ОСГ також можуть бути створені державами, які не є членами СС, за умови, що між нами існує правова основа для їх створення (міжнародно-правовий документ, двоабо багатостороння угода або національне законодавство) [10]. Також може бути досягнута угода про те, що особи, які не є представниками компетентних органів держав, що створили ОСГ, беруть участь у діяльності групи [9]. Так, Свропол та Свроюст активно надають різного роду підтримку та допомогу ОСГ у їхній діяльності [11, с. 7].

Кожна сторона угоди про ОСГ призначає керівника групи, який відповідає за нагляд за діяльністю ОСГ на території відповідної держави, та членів групи, які здійснюють слідчі заходи та оперативну діяльність. Коли останні присутні та беруть участь у розслідуванні за межами держави походження, вони мають статус «прикомандированих членів» [6, с. 8]. Керівником групи виступає представник сторони, на території якої група провадить свою діяльність, яка, у свою чергу, має здійснюватися згідно із законодавством відповідної держави. Прикомандировані члени мають право бути присутніми під час провадження слідчих дій, однак керівник групи може з певних причин прийняти інше рішення відповідно до законодавства сторони, на території якої провадиться діяльність. Окрім цього, керівник групи може ввірити прикомандированим членам завдання з провадження окремих слідчих дій, якщо це схвалено компетентними органами сторони проведення операції та сторони, яку вони представляють [9].

Метою діяльності Об'єднаної слідчої групи, створеної для розслідування катастрофи рейс МН17, є:

- встановлення фактичних обставини справи;

- встановлення правди про те, що сталося;

- встановлення осіб, відповідальних за катастрофу;

- збір кримінальних доказів для судового переслідування [12].

До складу групи увійшли представники Нідерландів, України, Австралії, Бельгії та Малайзії. Розслідування підтвердило, що літак було збито ракетою, встановленою на ракетно-повітряному комплексі Бук. 19.06.2019 р. Державна прокуратура Нідерландів оголосила, що буде переслідувати в судовому порядку чотирьох підозрюваних [13]. Кримінальне провадження буде здійснюватися в Нідерландах відповідно до кримінально-процесуального законодавства Нідерландів. Щоб мати можливість провести судовий розгляд у Нідерландах, Нідерланди і Україна підписали угоду про міжнародне правове співробітництво щодо злочинів, пов'язаних зі збиттям літака рейсу МН17 Малайзійських авіаліній 17 липня 2014 р. [14]. На сьогоднішній день розслідування Об'єднаної слідчої групи продовжується, адже вона вважає, що, окрім чотирьох підозрюваних, відповідальність за катастрофу несуть набагато більше осіб [13].

Діяльність описаних вище слідчих груп та положення нормативних актів, що іiі регулюють, свідчить про наявність у таких органів ознак, що характерні для процедури встановлення фактів як одного із засобів мирного вирішення міжнародних спорів. Завданнями як технічного, так і кримінального розслідування було встановлення фактичних обставин справи та вироблення на їх основі відповідних висновків. Вони створювались відповідно до положень міжнародних нормативно-правових актів, до їх складу входили представники різних заінтересованих держав, розслідування проводилися створеними для цього органами зі спеціальною компетенцією, що мали характер органів ad hoc. Водночас такі органи є доволі специфічним механізмом, що більшою мірою стосується ОСГ, адже їм притаманні певні особливості. По-перше, їхня діяльність координувалась національними органами (РБН та прокуратурою Нідерландів), що ставить під сумнів їхню повну незалежність та неупередженість. По-друге, здебільшого членами таких органів були представники заінтересованих держав, а так званий «іноземний елемент» - наявність у складі представників держав, які не мають власного інтересу - відсутній. По-третє, члени Об'єднаної слідчої групи залежно від того, на території якої держави проводилось розслідування, мали різний правовий статус.

Окрему увагу слід звернути на те, що повноваження зазначених органів, окрім встановлення фактів, полягали у наданні рекомендацій та встановленні індивідуальної відповідальності. Слідча група, яка проводила технічне розслідування, встановила причини катастрофи, проаналізувала практику діяльності держав та інших суб'єктів 
стосовно цивільних польотів над зонами збройних конфліктів і виробила на їх основі рекомендації щодо вдосконалення положень відповідних нормативних актів та поведінки суб'єктів міжнародного й національного права в цьому аспекті. ОСГ також встановлювала фактичні обставини справи та виробила висновки щодо індивідуальної відповідальності осіб, імовірно винних у катастрофі. Такі повноваження не є характерними для традиційної процедури розслідування. Разом із тим процедура встановлення фактів, що використовується у міжнародних відносинах, еволюціонувала, а компетенція органів,

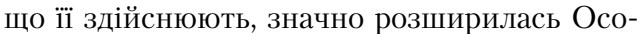
бливо це стосується органів зі встановлення фактів, які створюються в рамках Організації Об'єднаних Націй. Звичайною практикою $є$ наділення слідчих комісій ООН компетенцією з вироблення правових висновків, встановлення відповідальності та надання рекомендацій щодо мирного врегулювання.

\section{Висновки}

3 огляду на вищесказане, можна дійти висновку, що описані слідчі групи можна відносити до міжнародних органів зі встановлення фактів зі своїми специфічними особливостями. Їхня діяльність сприяла встановленню істини та ідентифікації осіб, винних у катастрофі. Окрім цього, рекомендації групи, що здійснювала технічне розслідування, якщо вони будуть втілені у життя, дозволять удосконалити міжнародно-правове регулювання цивільних авіаперевезень та попередити авіакатастрофи у майбутньому.

\section{Список використаних джерел:}

1. Резолюция Совета Безопасности ООН 2166 (2014) от 21 июля 2014 г. S/ RES/2166(2014)//United Nations Digital Library. URL: https://undocs.org/ru/S/RES/2166(2014) (дата звернення: 23.04.2020).

2. Конвенція про міжнародну цивільну авіацію 1944 р. // База даних «Законодавство України». URL: https://zakon.rada.gov.ua/laws/ show/995 038 (дата звернення: 21.04.2020).

3. Annex 13 to the Convention on International Civil Aviation. Aircraft Accident and Incident Investigation. URL: https://www.emsa.europa.eu/ retro/Docs/marine_casualties/annex_13.pdf (дата звернення: 21.04.2020).

4. Agreement between the National Bureau of Air Accident and Incidents Investigation with Civil Aircraft (NBAAII) of Ukraine and the Dutch Safety Board of the Netherlands on Delegation of Investigation in Respect of Aircraft Accident Involving Boeing 777-200, Registration: 9M-MRD "MALAYSIA AIRLINES" Flight MH17 of
23July 2014. URL:https://legacy.gscdn.nl/archives/ images/Agreement_NBAAI_and_DSB_website.pdf (дата звернення: $2 \overline{1} .04 .2020)$

5. Crash of Malaysia Airlines flight MH17. The Report of 13 October 2015 issued by the Dutch Safety Board. URL: https://www.onderzoeksraad.nl/ en/media/attachment/2018/7/10/debcd 724fe7breport_mh17_crash.pdf (дата звернення: 21.04.2020).

6. Joint investigation teams practical guide of 14 February 2017. URL: http://www.eurojust. europa.eu/doclibrary/JITs/JITs\%20framework/ JITs\%20Practical\%20Guide/JIT-GUIDE-2017-EN. pdf (дата звернення: 22.04.2020)

7. Council act of 29 May 2000 establishing in accordance with Article 34 of the Treaty on European Union the Convention on Mutual Assistance in Criminal Matters between the Member States of the European Union 2000/C 197/01. URL: http://www.eurojust.europa.eu/doclibrary/JITs/ JITs\%20framework $/ 2000 \% 20$ EU\%20Mutual\%20 Legal\%20Assistance\%20Convention/CAonMLA2000-05-29-EN.pdf (дата звернення: 22.04.2020).

8. Council Framework Decision of 13 June 2002 on joint investigation teams 2002/465/JHA. URL: http://www.eurojust.europa.eu/doclibrary/ JITs/JITs\% 20 framework/Framework\% 20 Decision\%202002-465-JHA\%20on\%20JITs/ CFDonJITs-2002-06-13-EN.pdf (дата звернення: 22.04.2020).

9. Второй дополнительный протокол к Европейской конвенции о взаимной правовой помощи по уголовным делам от 08 ноября 2001 г. URL: https:// rm.coe.int/CoERMPublicCommonSearchServices/ DisplayDCTMContent?documentId=090000168099 4ef5 (дата звернення: 22.04.2020).

10. Joint Investigation Teams. Legal framework. URL: http://www.eurojust.europa.eu/ Practitioners/JITs/Pages/legal-framework.aspx (дата звернення: 22.04.2020)

11. Agreement between Eurojust and Europol of 2010. URL: http://www.eurojust.europa.eu/ doclibrary/Eurojust-framework/agreements/ Agreement $\% 20$ between $\% 20$ Eurojust $\% 20$ and\%20Europol\%20(2010)/Eurojust-Europol2010-01-01-EN.pdf (дата звернення: 23.04.2020).

12. The criminal investigation. URL: https:// www.government.nl/topics/mh17-incident/ achieving-justice/the-criminal-investigation (дата звернення: 23.04.2020).

13. The criminal investigation by the Joint Investigation Team (JIT). URL: https:// www.prosecutionservice.nl/topics/mh17-planecrash/criminal-investigation-jit-mh17 (дата звернення: 24.04.2020).

14. Угода між Україною та Королівством Нідерландів про міжнародне правове співробітництво щодо злочинів, пов'язаних зі збиттям літака рейсу МН17 Малайзійських авіаліній 17 липня 2014 року від 7 липня 2017 р. // База даних «3аконодавство Украӥни». URL: https://zakon.rada. gov.ua/laws/show/528_002-17 (дата звернення: 24.04.2020). 
Artem Ivanov. International legal fundamentals of activities of bodies investigating the Boeing 777 disaster on the territory of Donetsk region

The article is devoted to the analysis of the activities of two international investigative teams whose task was to conduct a technical investigation into the causes and circumstances of the Boeing 777-200ER crash, which was shot down over the territory of Donetsk region on July 17, 2014, and criminal investigation the purpose of which is to identify those responsible for the disaster. The provisions of the Convention on International Civil Aviation 1944 and its Annex 13, which regulate various aspects of the technical investigation of civil aviation crashes, are analyzed. There are also analyzed the normative acts governing the activities of the Joint Investigation Teams, which are a mechanism of international cooperation based on an agreement between the competent authorities of two or more States established for a limited period and for the specific purpose of conducting criminal investigations in one or more interested States. The reasons for such investigations, their purpose and tasks, the subjects authorized to set up the respective investigative teams, the competence and powers of such groups, the issues related to the appointment of their members, etc., are investigated. The article defines the international legal nature and analyzes the direct activities of the investigative teams set up to investigate a specific event - the crash of an MH17 scheduled flight over Ukraine. The results of the activities of these bodies are investigated, which are to establish the actual circumstances of the case, to draw conclusions on the causes of the catastrophe, to establish the individual responsibility of the persons guilty of its commitment and to provide recommendations aimed at preventing such cases in the future. The article also examines whether these investigative teams can be referred to international fact-finding bodies. The author concludes that such investigative teams have the characteristics inherent in international investigative commissions and their own specific features that distinguish them from traditional fact-finding bodies.

Key words: fact finding, inquiry, commissions of inquiry, investigative teams, international investigation, air crashes, civil aviation. 